\title{
Maciej Mazur
}

(D) https://orcid.org/0000-0002-6375-2002

Instytut Literaturoznawstwa, Uniwersytet Śląski

\section{Opowieści przepełnione wstydem}

\author{
Maciej Zaremba Bielawski: Dom z dwiema wieżami. \\ Przeł. Mariusz Kalinowski. \\ Kraków, Wydawnictwo Karakter, 2018, ss. 320. \\ Włodek Goldkorn: Dziecko w śniegu. Przeł. Joanna Malawska. \\ Wołowiec, Wydawnictwo Czarne, 2018, ss. $256^{1}$.
}

\section{Tales Filled with Shame}

\begin{abstract}
Aвstract: The text is a discussion and comparison of two books by authors representing the postmemory generation who fled Poland after the events of March '68. Dziecko w śniegu by Włodek Goldkorn and Dom $z$ dwiema wieżami by Maciej Zaremba Bielawski, respectively written for Italian and Swedish audience, are to acquaint their primary readers with important cultural and historical events of 20th-century Poland. The present interpretative essay includes issues touched upon by the two authors: anti-Semitisms, the Holocaust witnesses' silence, childhood in post-war Poland, description of communist realities, the role of memory. Differences between the writers relating to their attitudes, style, and the question of Jewish identity are presented.
\end{abstract}

Dziecko w śniegu oraz Dom $z$ dwiema wieżami to dojrzałe, osobiste, wspomnieniowe książki napisane po mistrzowsku przez autorów, którzy w latach młodości opuścili Polskę po wydarzeniach Marca '68 i wybili się literacko za granicą. Omówienie tych brawurowo napisanych pozycji wypada zacząć od porównania ich paralelnej budowy.

Niektóre rozdziały Domu $z$ dwiema wieżami Macieja Zaremby Bielawskiego przedzielono krótkimi fragmentami mającymi wieńczyć i zapowiadać

\footnotetext{
${ }^{1}$ Cytaty z omawianych książek oznaczam w tekście za pomocą skrótów: Dom z dwiema wieżami - DDW, i Dziecko w śniegu - DŚ.
} 
poszczególne wątki, ale też rozrywać ciągły tekst. Wyizolowane bielą niezapisanej przestrzeni są w swej strukturze monadyczne; można je czytać osobno, tak jakby istniały same w sobie, poza kontekstem narracji. Zbliżoną strukturę ma pierwszy rozdział Dziecka w śniegu Włodka Goldkorna, opatrzony numerem 0 - autor wyjaśnia w nim, skąd wziął się tytuł książki. Zwraca też uwagę na kwestię podstawową, łączącą obie te opowieści - na milczenie: nienazywalność, niedopowiedzenie, nie-mowę. U Goldkorna takie fragmenty nie pojawiają się już potem, zostają zastąpione przez zdjęcia towarzyszącej pisarzowi w podróżach Neige De Benedetti. Można byłoby zapożyczyć ową numerację i wspomniane całostki tekstu Bielawskiego również opatrzyć cyfrą 0 - pełnią bowiem one tę samą funkcję, co u Goldkorna, są podstawą, fundamentem, a zarazem dopełnieniem treści kolejnych rozdziałów. Jeden $z$ fragmentów jest wiążący i dotyczy zachowania matki Macieja Zaremby Bielawskiego, które należałoby zinterpretować przynajmniej dwojako:

Kiedy ona dwadzieścia lat później opowiada swoją historię, to nie swemu synowi. Opowiada ją jego żonie, która jest pisarką. Nagrywają te rozmowy, jest ich ponad sto godzin. Gdy mama zdaje sobie sprawę, że nie powstanie z nich książka, w każdym razie nie teraz, niszczy taśmy. Nie wyrzuca tych kaset i nie pali ich. Wkłada je do magnetofonu i przyciska record. Godzinę za godziną swoich wspomnień pokrywa odgłosem domowej krzątaniny i szumem samochodów na Hornsgatan.

DDW, s. 261

Lila Immerdauer, jak nazywała się niegdyś matka pisarza, zniszczyła taśmy z nagraniem swojego głosu w przedziwny sposób. Ze zrozumiałych zdań i wyrazistych słów stworzyła bełkot.

Jej historia, jak możemy przeczytać w Domu $z$ dwiema wieżami, nie jest opowieścią jednej z tych Żydówek, które przeżyły obóz zagłady. Lili wraz z matką udało się wyrwać z getta, a pomogło im około trzydziestu sześciu osób. Jak przypuszcza Bielawski - gdyby było ich mniej, zapewne kobieta nie przetrwałaby wojny (DDW, s. 195). Sądzę, że jej decyzja o zniszczeniu nagrań nie wynikała $\mathrm{z}$ tego, że na taśmach znajdował się jakiś ważny i wiążący fragment, którego nie chciałaby opublikować. Skłaniałbym się ku temu i tak to interpretuję, że zdała ona sobie sprawę z tego, że opowiedziała historię, która powinna zostać niewypowiedziana, stworzyła narrację wymijającą doświadczenie jej prawdziwej traumy, spostrzegła, że to, co jest na taśmach - zaledwie po kilku miesiącach straciło ważność: nadeszły nowe sny, pojawiły się nowe słowa, znów przemówili ci, którzy już nie żyją, i trzeba by było opowiadać wszystko na nowo ${ }^{2}$. Bełkot,

${ }^{2}$ Warto w tym kontekście zwrócić uwagę na pierwsze słowa trzeciego rozdziału, który nomen omen nosi tytuł Lila: „»Twój dziadek? Sprał jednego łajdaka po mordzie! Na samym rynku!« To nie jest język mamy. Mama nie używa grubych słów” (DDW, s. 111). Matka Bielawskiego zaraz po wypowiedzeniu tych zdań milknie i nie chce dalej mówić. Ileż razy podczas tych wywiadów 
szum, pokawałkowane wyrazy - może to był jedyny sposób na wyrażenie tego, czego nie można wyrazić: niezrozumiała opowieść świadka Holokaustu wymieszana z niepojętą muzyką życia ze świata po Auschwitz. Taśmy, na których jedno i drugie (stopione ze sobą) przestaje być „ludzkim językiem”.

Wspomniane nagrania są przede wszystkim palimpsestami. Krótki fragment, który oznaczyłbym numerem zero, można potraktować jako metaforyczną i sugestywną definicję postpamięci. Nałożenie własnego głosu na głos świadka oba je stapia i znosi; postpamięć ${ }^{3}$ to odsłuchanie nagrania i uznanie go za głos własny.

Bielawski (ur. 1951) i Goldkorn (ur. 1952) są reprezentantami pokolenia postpamięci. Obaj opuścili Polskę niedługo po wydarzeniach Marca '68, kiedy w kraju znów zapanowały silne nastroje antysemickie. Losy dziennikarzy ułożyły się jednak odmiennie: Bielawski wyjechał z matką, babcią i braćmi do Szwecji, Goldkorn przebywał wraz z rodzicami w Izraelu, potem przeprowadził się do Włoch.

Wspomnienia obu autorów z okresu dzieciństwa zasługują na szczególną uwagę. Bielawski szerzej niż Goldkorn opisuje ten okres, ujawniając już w kilku pierwszych zdaniach swoją niezwykłą wrażliwość językową. Reminiscencje spisuje, naśladując dziecięcy sposób mówienia. Dziecko, ucząc się, powtarza, nazywa, referuje, opowiada sobie samemu, co widzi, i nieustannie dopytuje się: „Edek wypala papierosa do połowy i daje mu zgasnąć. [...] Edek we wszystkim jest oszczędny. [...] Edek porusza się ostrożnie. [...] Jest bardzo chudy i nosi za duże ubrania. Mówi się o nim wujek Edek" (DDW, s. 7). Język dojrzewa stopniowo wraz z Maciejem. Stylizacja jest oczywista, mimo że tekst przeplatają różne dygresje czy komentarze. Dzięki niej początek książki zyskuje tyleż wymiar ironiczny, ile komiczny. Jednak autor powoli rezygnuje z komizmu, który od pewnego momentu nie będzie już na miejscu - ową cezurą jest chwila, gdy nastoletni Maciej dowiaduje się, że jego mama jest Żydówką. Ironia natomiast towarzyszy pisarzowi już do końca ${ }^{4}$. Jej ostrze wymierzone jest szczególnie w stronę narodowych mitów, źródeł polskiego antysemityzmu, nacjonalizacji

zdarzyło jej się podobnie zamilknąć, ileż razy użyła nieadekwatnych słów? Na te pytania pisarz nie udziela odpowiedzi.

${ }^{3}$ W ujęciu Marianne Hirsch postpamięć cechują: silna, prywatna więź, pokoleniowy dystans, a także stosunek do przedmiotu lub źródła zapośredniczony przez wyobraźnię i kreację. „Postpamięć charakteryzuje doświadczenie tych, którzy dorastali w środowisku zdominowanym przez narracje wywodzące się sprzed ich narodzin. Ich własne spóźnione historie ulegają zniesieniu przez historie poprzedniego pokolenia ukształtowane przez doświadczenie traumatyczne, którego nie sposób ani zrozumieć, ani przetworzyć" (M. Hirsch: Żałoba i postpamięć. Przeł. K. Bojarska. W: Teoria wiedzy o przeszłości na tle współczesnej humanistyki. Antologia. Red. E. Domańska. Poznań 2010, s. 254).

${ }^{4}$ Bielawski rzecz jasna nie ironizuje, opisując skalę zbrodni nazistowskich czy zniszczenie Warszawy etc. 
religii ${ }^{5}$. Autor po wielokroć opisuje w ten sposób wydarzenia przykre i hańbiące; na tym tle najlepsze literacko są sceny, w których za pomocą ironii próbuje oddać niejasną i trudną do uzmysłowienia sobie, zwłaszcza dla zachodnich obywateli i prymarnych odbiorców tej książki, absurdalną rzeczywistość polskiego komunizmu ${ }^{6}$. Znakomitym epizodem jest tutaj „przygoda $\mathrm{z}$ bananem”, od której zaczęło się pisanie Domu $z$ dwiema wieżami ${ }^{7}$. Podczas rozruchów studenckich w 1968 roku uczestników protestu wytykano palcami - mówiono, że to „bananowa młodzież”, co oznaczało: młodzież rozpasana i rozpuszczona. Siedemnastoletni Bielawski postanowił się więc zaangażować - kupił banana, co mogło zrujnować budżet przeciętnego obywatela, po czym zdecydował, że jedząc go, przespaceruje się ulicami Warszawy. Skórkę ostentacyjnie wyrzucił za siebie przed Domem Partii.

Włodek Goldkorn pisze stylem zdecydowanie bardziej stonowanym. Pojawia się też w jego utworze więcej tematów związanych bezpośrednio z Zagładą niż w tekście Bielawskiego: opisy Auschwitz, Treblinki etc. Zaskakujące jest, co podkreśla, jego zżycie się już $\mathrm{w}$ dzieciństwie z symbolami nazistowskimi: „[...] tych talerzy i sztućców, również oznaczonych swastyką, używaliśmy na co dzień. [...] Swastyki stały się moją codziennością, oswojoną częścią mojego dziecięcego imaginarium i moich fantazji" (DŚ, s. 20). Z żydowskimi kolegami z podwórka "bawił się w Auschwitz” - a była to niewinna zabawa ${ }^{8}$. O obozach zagłady mówiło się często. Dzieci przejmowały więc słownik rodziców, ale miały mgliste pojęcie o tym, co rzeczywiście się tam działo: w dziecięcych grach ktoś był esesmanem, ktoś ofiarą - czysta mimikra. Goldkorn jest potomkiem Żydów i komunistów, którzy ocaleli, uciekając na Wschód: najpierw Lwów, potem Donbas, później Kazachstan; większość ich przyjaciół w Polsce została wymordowana - kilkoro ocalało. Pisarz nigdy nie miał problemu z określeniem swojej

${ }^{5}$ Por. J.S. Bystroń: Megalomania narodowa. Warszawa 1995, s. 20-29. Warto zwrócić szczególną uwagę na opisany przez Bystronia proces nacjonalizacji religii, o którym również - żartobliwie, lecz ostro - pisze Bielawski.

${ }^{6}$ Adresatem książki jest przede wszystkim szwedzki czytelnik. Prosty, rzeczowy opis ma służyć zaznajomieniu go z najważniejszymi zdarzeniami z historii Polski w XX wieku. Podobnie jest z Dzieckiem w śniegu (wydanym we Włoszech w 2016 r.). Szczególnie jednak Dom z dwiema wieżami można czytać jako odpowiedź na politykę historyczną obecnego rządu polskiego. Data pierwszego polskiego wydania książek zbiega się z 50. rocznicą Marca '68, a także z zaostrzeniem się stosunków dyplomatycznych na linii Izrael - Polska w związku z przyjęciem przez Sejm RP w styczniu 2018 r. nowelizacji ustawy o Instytucie Pamięci Narodowej - Komisji Ścigania Zbrodni przeciwko Narodowi Polskiemu, co czyni te utwory tym bardziej aktualnymi. Dla prymarnego odbiorcy są więc nie tylko skrótowym kompendium traktującym o relacjach polsko-żydowskich, ale też swego rodzaju "głosem z prasy”, który ma rozjaśnić, być może enigmatyczną dla włoskiego czy szwedzkiego czytelnika, kwestię punktów spornych w stosunkach izraelsko-polskich.

7 Bielawski wspomina o tym w wywiadzie udzielonym Włodkowi Nowakowi. Zob. http:// wyborcza.pl/10,155173,23872744,jesli-nasze-zycie-jest-opowiescia-to-o-czym-opowiada-maciej. html?disableRedirects=true [data dostępu: 17.03.2019].

${ }^{8}$ Por. Z. NaŁkowska: Dorośli i dzieci w Oświęcimiu. W: Taż: Medaliony. Warszawa 1968. 
tożsamości, od zawsze czuł się Żydem, chodził do szkoły, gdzie większość dzieci była pochodzenia żydowskiego, w jego domu rozmawiało się o Holokauście, polityce. Zupełnie inaczej było u Zaremby Bielawskiego. Jego matka milczała, dopóki mogła, a on niemalże do osiągnięcia pełnoletności nie wiedział, że jest Żydem. $\mathrm{Z}$ tego zestawienia, mimo wszystko, wynikają dwa podobne spojrzenia na kwestię pamięci.

Goldkorn, wieloletni przyjaciel Marka Edelmana, wspomina często, że „pamięć jest pamięcią, gdy osnuta jest mgłą i ulega ciągłym zmianom, czyli kiedy jest żywa” (DŚ, s. 78), i że nie wszystkie wspomnienia muszą być weryfikowalne. Podkreśla, że nie jest i nie czuje się ofiarą, ale podmiotem historii: „[...] dla mnie pamięć o Shoa oznacza umiejętność posługiwania się językiem rewolty i przekazywania go innym, oznacza nieustanną, radykalną kontestację prawd władzy" (DŚ, s. 160). Pamięć ma służyć obronie pokrzywdzonych. Obronie przed tymi, którzy, jak znaczna część pozbawionej wrażliwości izraelskiej młodzieży, nazywają swoich rodaków - ocalałych z obozów śmierci, tych $\mathrm{z}$ wytatuowanymi numerami na przedramionach - mydłem, powtarzając nieustannie, że ci, którzy nie przetrwali, nie stawili oporu, byli jak „owce prowadzone na rzeź” (DŚ, s. 134). Wiąże się to z zupełnym niezrozumieniem oraz brakiem wyobraźni i empatii $\mathrm{w}$ stosunku do tych-którzy-przeżyli. Goldkorn przeciwstawia im zawołanie Nachci ${ }^{9}$, która z dzieckiem na rękach poszła do komory gazowej: „[...] ten świat nie jest mnie godzien" (DŚ, s. 159). Kiedy pomyśli się o Sabrach wykrzykujących „mydło” czy izraelskim oficerze, który kazał Włodkowi wycelować broń w bezbronne arabskie dziecko, zapewne mając jeszcze w pamięci słynny obrazek $\mathrm{z}$ getta (chłopca $\mathrm{z}$ podniesionymi rękami ${ }^{10}$ ), ani przez chwilę się nie dziwimy, że pamięci trzeba używać jak oręża. Zło - powiada Goldkorn - ma wielki urok. Trzeba walczyć, ale jak wspomina Bielawski za Gombrowiczem - zło można stłamsić tylko w sobie...

Autor Dziecka w śniegu chce walczyć z postępującą wulgaryzacją i niezrozumieniem Zagłady: z elementarnym brakiem empatii, ze skostniałymi wyrażeniami, które przylgnęły (na przykład do Żydów) po drugiej wojnie światowej. Bielawski robi podobnie, nieco jednak mocniej krytykując to, co nazywa polskim antysemityzmem. Stawia tezę, że polska tożsamość narodowa po odzyskaniu niepodległości w 1918 roku kształtowała się na zasadzie dość prostego mechanizmu: w opozycji do innego, a tym innym miał być Żyd. Można by to zamknąć w formule: jesteś zatem „prawdziwym Polakiem”, jeśli nie jesteś Żydem lub jeśli stajesz w kontrze do tzw. żydostwa. Tego typu stwierdzenia

${ }^{9}$ Nachcia była siostrą matki Goldkorna, jej imię jest zdrobnieniem od Noego - tego, który miał ocalić lud. Nachcia nie oddała dziecka przed wejściem do komory gazowej - weszła tam, trzymając je na rękach, wypowiadając cytowane słowa.

10 „Jestem przekonany, że sierżant wiele razy widział fotografię chłopca z uniesionymi rękami na ulicy warszawskiego getta [...]. Ale samo zobaczenie obrazu nic nie daje, jeśli nie ma kogoś, kto by go wytłumaczył: ten obraz mówi o tobie" (DŚ, s. 141-142). 
były osią polityki Romana Dmowskiego. Autor bardzo ostro krytykuje jego poglądy: „[...] w roku 1939 mieszkało w Tarnowie, gdzie mama zdawała maturę, dwadzieścia pięć tysięcy Żydów. Dziś nie ma żadnego. [...] Roman Dmowski otrzymał własną ulicę. Broń Boże nie za swoje poglądy na temat Żydów. O tym już się nie pamięta. W podzięce za swe zasługi dla odzyskania niepodległości” (DDW, s. 171). Chwilami jednak Bielawski ociera się o pewną przesadę - niektóre wtrącenia (przykładowo, „Fe, ależ jestem niesympatyczny” - DDW, s. 157) tchną pretensjonalnością.

Goldkorn (powtórzmy: potomek Żydów i komunistów ${ }^{11}$ ) bywa bardziej oględny, miejscami aluzyjny. Nawiązuje głównie do czasów powojennych zwraca uwagę na ich absurdalność i skomplikowanie:

Kilka lat temu rozmawiałem z jednym z ojców opozycji demokratycznej, intelektualistą pochodzenia żydowskiego, synem komunistów. [...] rozmawialiśmy [...] o tym, że podczas gdy nasi ojcowie otrzymywali mieszkania, pensje i przywileje, inni polscy patrioci, prawdziwi bohaterowie, często osoby, które pomagały Żydom, byli zamykani w więzieniach, torturowani [...]. Nie chodziło w tej rozmowie o odpieranie argumentów, o to, czyja krzywda większa. Chcieliśmy sobie nawzajem potwierdzić, że historia jest pełna paradoksów, a pamięć może być uwarunkowana przez punkt widzenia tych, którzy ją kultywują.

DŚ, s. 62-63

Szczególnie ostatnie zdanie wydaje się tu ważkie. Pisząc o tym, co działo się podczas wojny i później, warto pamiętać, aby działać przeciw uproszczeniom.

Obaj pisarze podobnie traktują kwestię milczenia jednostki, funkcję zapominania. Ujmują to bardzo ciekawie: Goldkorn w odniesieniu do swoich rodziców, a Bielawski, komentując, dlaczego jego matka milczała od 1946 roku do momentu, kiedy powiedziała synowi: „Wyjeżdżamy. Jestem Żydówką” (DDW, s. 102).

Może tę pustkę, taką mam hipotezę, trzeba było wypełnić systematycznie pamięcią, która była niczym innym jak pozbywaniem się wspomnień: żeby uciec

${ }^{11}$ Ojciec Włodka był „dziennikarzem jidysz” (DŚ, s. 60) i aktywistą Centralnego Komitetu Żydów w Polsce, nie przyjął posady w Urzędzie Bezpieczeństwa ani propozycji pracy w PZPR, działał na rzecz ocalałych z Holokaustu. Goldkorn opisuje, jak ojciec w 1963 r. na zlecenie dziennika został wysłany do Auschwitz, gdzie znalazł unurzany w błocie modlitewnik. Pomyślał wtedy, że należał on do jego matki Jachwety. Zaraz potem zemdlał - poczuł, że duch matki (dybuk) w niego wstąpił. Do pewnego stopnia paralelna jest podróż Włodka Goldkorna, który traktuje ją jako powrót do domu (domu-Muzeum). Idąc ścieżką prowadzącą kiedyś do komory gazowej, podobnie jak jego ojciec, który „poczuł ducha swojej matki” (DŚ, s. 186), stara się utożsamić z ludźmi przemierzającymi tę drogę w 1943 r. Podróż Włodka Goldkorna opisana w drugiej części książki to wędrówka człowieka, który stara się utożsa mić, który stara się zrozumieć, ale w końcu pojmuje (wzywając dybuka - ducha jego babci, by w niego wstąpił), że to niemożliwe (DŚ, s. 191-192). 
od wyrzutów sumienia i żeby znaleźć powód do życia dalej w tym kraju i na ziemi nie do rozpoznania.

DŚ, s. 15

Milczy się po to, żeby stać się kimś innym i zapomnieć o swojej samotności.

DDW, s. 283

Różnica pomiędzy rodzicami Goldkorna a matką Bielawskiego jest oczywista - oni mówili, ona milczała, wielu jednak nigdy nie wyjawiło swojej historii, choćby ciotka Chajtele, która ocalała, porzucając swoje dziecko w śniegu. Autor Domu $z$ dwiema wieżami pisze książkę, by odpowiedzieć na pytanie nie tyle o to, kim jest, ale dlaczego jest. Przecież to, że Lila przeżyła wojnę, było nieprawdopodobnym przypadkiem. Ale dla kogo pisze? Dla nich - dla swoich rodziców, by głosem z odsłuchanego nagrania, głosem, który przyjął jako własny, opowiedzieć im ich historię, ponieważ wie, że nigdy nie wysłuchali się do końca, ponieważ wie więcej, niż oni wiedzieli kiedykolwiek o sobie ${ }^{12}$. Dom $z$ dwiema wieżami to rulon z listów, który autor wsunął do butelki i wyrzucił do morza, aby poniosło ją w odległą przeszłośćc ${ }^{13}$.

Goldkorn w swojej książce przekonuje, że odczuwa pewną fascynację związaną z nihilizmem. Sugeruje, że najważniejsze zawsze pozostaje niewypowiedziane. To, czym współcześnie stało się Auschwitz ${ }^{14}$, poddaje szerokiej krytyce i akcentuje, że nie ma i być nie może żadnej nauki, którą wyniosłoby się z obozów śmierci. Ujawnia tym samym, jak nonsensowne jest hasło: „nigdy więcej Auschwitz”. Nie chce racjonalizować Szoa i wszelkim takim próbom się przeciwstawia. Konstatuje, że świat po drugiej wojnie jest nie do naprawienia.

Zagłada to ostateczne unicestwienie kultury, pamięci. Zgładzić, zagładzić oznacza zrównać z ziemią wszystko, co niegdyś odznaczało się jakąś „chropowatością”, a więc przejawami życia; zagładzić to wypolerować, wyczyścić, wy-gładzić. Włodek Goldkorn chciałby zamiast Muzeum Auschwitz widzieć wielki czarny

12 Relacje między rodzicami pisarza były skomplikowane. Lila chciała unieważnienia poprzedniego małżeństwa Oskara, co w praktyce oznaczało zmuszenie go do „wyparcia się swojej rodziny” (DDW, s. 262). I tak, Lila wyszła za mąż za „Polaka z monoklem”, który przeżył drugą wojnę światową z godnością (sic!) - przebywając w oflagu. Żydówka, pamiętająca jeszcze getta ławkowe i szmalcowników, urodziła mu „polskie dzieci, z tarczą herbową i świadectwem chrztu” (DDW, s. 283); nietrudno się domyślić, że wiele przemilczała: „[...] gdyby opowiedziała więcej, on mógłby dostrzec jej otchłań i zląc się" (DDW, s. 283). Do tego wątku powracam w dalszej części tekstu.

${ }^{13}$ Nawiązuję tu do ujmującego fragmentu Domu $z$ dwiema wieżami: „Te listy nie są pisane do tego, kim byłem wtedy. To poczta butelkowa w czasie, do tego, kim będę za czterdzieści lat. O tato... Nie oczekujesz, że te słowa dotrą za twojego życia” (DDW, s. 280).

${ }^{14}$ Goldkorn opisuje także inne obozy: Treblinkę, Sobibór, które określiłby mianem cmentarza. Komentuję tutaj tylko jego refleksję na temat Muzeum Auschwitz, która wydaje mi się znacząca. Ten wątek wpisuje się w szerszą krytykę tamtejszych praktyk muzealnych, zob. J. KRAKowsKa: Obóz. W: Ślady Holokaustu w imaginarium kultury polskiej. Red. J. KowalsKa-Leder, I. Kurz, M. Szpakowska, P. Dobrosielski. Warszawa 2017, s. 275-319. 
dół, cmentarz; chciałby cały ten kompleks zburzyć, tak, żeby ział pustką; takie powinno być niewyrażalne - wielka ciemna przepaść połykająca wszelkie światło. Tymczasem Auschwitz stało się przede wszystkim lustrem ${ }^{15}$, powierzchnią wy-gładzoną, która zamiast połykać światło, odbija je, zniekształca, nie dając do siebie dostępu. Liczy się więc bardziej nasz stosunek do tej przestrzeni. Jedyna nauka, jaka może z tego płynąć, to nie nauka o Auschwitz, a o tym, co zostaje odbite $\mathrm{w}$ naszą stronę, zwrócone wraz ze spojrzeniem nań skierowanym - nauka o nas patrzących na to miejsce, nauka o języku, którym próbujemy je opisać. To, co w przyszłości zrobimy z Auschwitz, zaświadczy o zmieniającej się kulturze, o naszych przyzwyczajeniach, filozofii - oto, dlaczego chcę powiedzieć, że to miejsce jest zwierciadłem: odbija obraz współczesnego społeczeństwa, nie dając wcale dostępu do swej istoty; mówi o nas, nie o sobie. Pusty okrzyk: „nigdy więcej Auschwitz", świadczy o niezrozumieniu, ale tego pojąć się przecież nie da. Tak rozumiem słowa Goldkorna - nie da się sprofanować Auschwitz ${ }^{16}$; tak czytam fragment, w którym Goldkorn z pobłażaniem pisze o młodych chłopcach porównujących długość swoich penisów w toalecie w tym obozie.

Można się zatem pokusić o metaforyczną konkluzję: Auschwitz jest zwierciadłem - rozmija się z rzeczywistością, będąc nieustannie z nią splątane. Swą tajemnicę może wyjawić tylko czarnemu, nocnemu niebu.

Goldkorn, krytykując owo „muzeum okropności” (DŚ, s. 179), nawiązuje też bezpośrednio do teorii symulacji i symulakrów Jeana Baudrillarda - szczególnie, kiedy używa sformułowania „Disneyland horrorów” (DŚ, s. 194). Michał Kłosiński tak pisze o tym procesie: „[...] autentyczny napis [„Arbeit macht frei” - M.M.] zastąpiła kopia, należałoby zapytać, czy ten sam los spotka także obóz, który stanie się swoją własną symulacją, przeniesiony, niczym Disneyland, w inną przestrzeń z zachowaniem tych samych proporcji” ${ }^{17}$. Dla Goldkorna Auschwitz to konstrukt kulturowy, wyobrażona ikona, która nie jest i nie może być święta; stała się już własną symulacją, co niewiele zmienia - do jej istoty i tak byśmy się nie zbliżyli.

Bielawski pisze książkę przede wszystkim o swoich rodzicach. Stawia interesującą tezę, że jego matka milczała na temat Zagłady, a ojciec nie próbował $\mathrm{z}$ nią o tym rozmawiać, gdyż wydawało mu się, że to, co przeżywał, będąc w oflagu - obozie jenieckim dla oficerów - jest niemożliwe do zestawienia

${ }^{15} \mathrm{Na}$ marginesie warto przywołać pojęcie heterotopii Michela Foucaulta. Zwierciadło funkcjonuje jak heterotopia: ukazuje miejsce jednocześnie absolutnie realne i nierealne. Por. M. FouCault: Inne przestrzenie. Przeł. A. Rejniak-Majewska. „Teksty Drugie” 2005, nr 6, s. 120-121.

${ }^{16}$ „W Auschwitz nie ma nic świętego [...]. Profanacja? [...] Profanacja odnosi się do świętości i obrazu Auschwitz: obrazu, bo o rzeczywistości komór gazowych nie wiemy nic" (DŚ, s. 178). Ludzie tylko chcą „zakrzyczeć” to miejsce pojęciem świętości w lęku przed zmierzeniem się ze swoimi słabościami i skłonnością do Zła.

${ }^{17}$ M. KŁosı́́ski: Ratunkiem jest tylko poezja. Baudrillard - teoria - literatura. Warszawa 2015, s. 143. 
i pogodzenia z tym, co wtedy przechodziła Lila. W Domu $z$ dwiema wieżami znajdujemy rozdział zatytułowany On i Ona, który składa się z przeplatających się fragmentów równolegle przedstawiających losy Oskara - ojca Macieja, i Lili. $\mathrm{Na}$ końcu książki dodany został przypis wyjaśniający, czym były oflagi i jak obchodzono się $\mathrm{w}$ nich $\mathrm{z}$ jeńcami. Bielawski podkreśla, że to jedne $\mathrm{z}$ niewielu miejsc, w których w latach 40. XX wieku nadal respektowano kodeks honorowy i wojenne obyczaje ${ }^{18}$ - organizowano $\mathrm{w}$ nich biblioteki oraz specjalne zajęcia dokształcające; jeńcy właściwie nie zaznali tam głodu, a żydowskich oficerów, mimo rozkazów Heinricha Himmlera, skutecznie ukrywano i przetransportowywano, by nie zostali wysłani do gett i obozów zagłady na pewną śmierć. To niezwykłe, o czym pisze Bielawski: drugą wojnę światową przeżyli niemal wszyscy Żydzi z oflagów. Trudno sobie uzmysłowić, że w zawierusze tego czasu gdzieś ocalało (już reliktowe) pojęcie honoru. Splecenie narracji Lili z opowieścią o tym, co „porabiał” w oflagu Oskar, daje trudny do opisania efekt paranoiczny. Bielawski znakomicie to przedstawia, znów, tym razem szerszą partię tekstu znacząc ironią. Jako dziecko ćwiczył „twarz Bustera Keatona”: „[...] chcę być Busterem Keatonem, chcę być niedosiężny. W łazience ćwiczę tę maskę. Oczy mówią: "nikt nie zgłębi smutku mego serca " (DDW, s. 50). Właśnie tak wyobrażam sobie Zarembę Bielawskiego - to autor, który pisze z twarzą Bustera Keatona, a wspomniany rozdział dobitnie o tym świadczy.

Dziecko w śniegu i Dom $z$ dwiema wieżami to pięknie wydane ${ }^{19}$, przełożone odpowiednio z języka włoskiego i szwedzkiego książki, które na pewno pogłębiają świadomość zagranicznych czytelników, przybliżając im szczególnie realia polskiego komunizmu i kulisy wydarzeń Marca '68. Goldkorn pisze bez emfazy, klasycznie; jest delikatny tam, gdzie wypada być delikatnym, podnosi głos, kiedy trzeba zaprotestować - jest subtelny i oględny, chciałoby się rzec: cichy, nawet gdy wspomina o żydowskich sztetlach, które w obiegowej opinii były ogniskami żydowskiego folkloru, a w rzeczywistości „synonimem zacofania” (DŚ, s. 31). Bielawski natomiast „szuka metafor, które ranią” (DDW, s. 136). Jak powiedział w jednym z wywiadów, zapytany o to, czy czuje się Szwedem: „[...] jest bardzo dobry wyznacznik tożsamościowy - odpowiedź na pytanie - za kogo się wstydzimy". Wstydzi się więc za Szwecję, za Polskę, za Izrael ${ }^{20}$. Goldkorn z kolei

${ }^{18}$ Autor wspomina historię trzech braci Bielawskich herbu Zaremba, którzy brali udział w bitwie pod Grunwaldem. W książce pojawia się nierzadko „ocalające” według Bielawskiego pojęcie honoru, przynależące do tych, którzy „patrzą wstecz na świat, który minął” (DDW, s. 308). W tym kontekście należałoby osadzić tytuł książki: Dom $z$ dwiema wieżami - kojarzący się z rycerskim zamczyskiem - jest w istocie domem dla psychicznie chorych, gdzie dorasta mały Maciej. Rozdział On i Ona zachowuje podobną dwoistość.

${ }^{19}$ Warto tu zwrócić uwagę na zdjęcia umieszczone w obu książkach. Referentem niektórych fotografii Neige De Benedetti jest pustka - do niczego nie odsyłają. Por. A. Szczepan: Krajobrazy postpamięci. „Teksty Drugie” 2014, nr 1, s. 111.

${ }^{20}$ Zob. wywiad Katarzyny Janowskiej i Grzegorza Jankowicza z Maciejem Zarembą Bielawskim: https://www.youtube.com/watch?v=MMYfxeeh_Oc [data dostępu: 17.03.2019]. 
pisze: „[...] w opowieści o Dobru jest zwykle więcej wstydu niż w opowieści o Złu" (DŚ, s. 55) - i trudno się z tym nie zgodzić - obie te historie warto czytać razem. Ja odbieram je jako znakomicie napisane książki przepełnione wstydem.

Maciej Mazur - student Wydziału Humanistycznego Uniwersytetu Śląskiego. Studiuje w wymiarze indywidualnym pod kierunkiem dr hab. Marty Tomczok. Szczególnie zainteresowany twórczością Jarosława Iwaszkiewicza i Ewy Kuryluk. Publikował w „Ruchu Literackim” i „ArtPapierze”. 